\section{Annals of \\ Nutrition and \\ Metabolism}

\title{
How to Feed the Fetus
}

Guest Editor

Ferdinand Haschke, Salzburg

Editorial Board

Jatinder Bhatia, Augusta, GA

Weili Lin, Chapel Hill, NC

Carlos Lifschitz, Buenos Aires

Andrew Prentice, Banjul/London

Frank M. Ruemmele, Paris

Hania Szajewska, Warsaw 


\section{Sponsor Note}

This publication was supported by an unrestricted educational grant by the Nestlé Nutrition Institute. The institute is a not-for-profit association which was created to provide latest medical and scientific information to health professionals in the field of pediatric and adult nutrition and nutrition-related disorders (available at www.nestlenutrition-institute.org).

Any liability of the sponsors for the content of the papers is hereby expressly excluded.

\section{Disclosure Statement Guest Editor}

Ferdinand Haschke declares honoraria for scientific lectures from Nestlé and other food companies.

\section{S. Karger}

Medical and Scientific Publishers

Basel $\cdot$ Freiburg $\cdot$ Hartford $\cdot$ Oxford Bangkok $\cdot$ Dubai $\cdot$ Kuala Lumpur. Melbourne $\cdot$ Mexico City .

Moscow $\cdot$ New Delhi $\cdot$ Paris .

Shanghai $\cdot$ Tokyo
Disclaimer

The statements, opinions and data contained in this publication are solely those of the individual authors and contributor and not of the publisher and the editor(s). The appearance of advertisements in the journal is not a warranty, endorsement, or approval of the products or services advertised or of their effectiveness, quality or safety. The publisher and the editor(s) disclaim responsibility for any injury to persons or property resulting from any ideas, methods, instructions or products referred to in the content or advertisements.

Drug Dosage

The authors and the publisher have exerted every effort to ensure that drug selection and dosage set forth in this text are in accord with current recommendations and practice at the time of publication. However, in view of ongoing research, changes in government regulations, and the constant flow of information relating to drug therapy and drug reactions, the reader is urged to check the package insert for each drug for any change in indications and dosage and for added warnings and precautions. This is particularly important when the recommended agent is a new and/or infrequently employed drug.
All rights reserved.

No part of this publication may be translated into other languages, reproduced or utilized in any form or by any means, electronic or mechanical, including photocopying, recording, microcopying, or by any information storage and retrieval system, without permission in writing from the publisher or, in the case of photocopying, direct payment of a specified fee to the Copyright Clearance Center (see "General Information").

(C) 2021 S. Karger AG, Basel

P.O. Box, CH-4009 Basel (Switzerland)

e-ISBN 978-3-318-06859-7 


\section{Contents}

\section{Editorial}

Haschke, F. (Salzburg)

How to Feed the Fetus

3 Focus on: Gestational Diabetes Mellitus and Developmental Programming

4 Gestational Diabetes Mellitus and Developmental Programming

Chu, A.H.Y. (Singapore); Godfrey, K.M. (Southampton)

15 Focus on: Nutrition Management of Gestational Diabetes Mellitus

16 Nutrition Management of Gestational Diabetes Mellitus Kapur, K. (Bangalore); Kapur, A. (Bagsvaerd); Hod, M. (Tel Aviv)

28 Focus on: Prenatal Nutritional Strategies to Reduce the Risk of Preterm Birth

29 Prenatal Nutritional Strategies to Reduce the Risk of Preterm Birth

Best, K.P.; Gomersall, J.; Makrides, M. (Adelaide, SA)

37 Focus on: Maternal Undernutrition before and during Pregnancy and Offspring Health and Development

38 Maternal Undernutrition before and during Pregnancy and Offspring Health and Development Young, M.F.; Ramakrishnan, U. (Atlanta, GA) 
Annals of

Nutrition and

Metabolism

\section{Policy Statement}

The Nestlé Nutrition Institute was created to provide health professionals with up-to-date information on nutrition and nutritionrelated disorders in order to enable them to continuously improve patient care based on the latest medical and scientific developments.

One of the key pillars of the Nestlé Nutrition Institute is Annales Nestlé, a pediatric journal that has been published on a regular basis since 1942. It contains review articles on clinical practice and research in all fields of pediatrics with focus on nutrition.

Annales Nestlé appears three times a year. Each article is supported by a Focus Page, and each issue by an Infographic illustrating the core topic. Published on www.nestlenutrition-institute.org as well as in print, Annales Nestlé is one of the most widely read pediatric journals in the world.

Annales Nestlé is edited by an independent editorial board of opinion leaders in pediatric research, thus guaranteeing the medical and scientific impartiality of the journal, and hence the high regard it enjoys in medical and scientific circles. The editorial board sets the editorial policy, identifies topics to be addressed, selects authors, and oversees the review process for each issue.

Every issue of Annales Nestlé initially appears as a supplement to Annals of Nutrition and Metabolism - a journal from Karger Publishers, Basel, Switzerland - and is listed in all major bibliographic services, such as Medline, PubMed, and Web of Science. This has been our practice since 2011.

We are pleased to offer you our innovative product, which results from a creative and effective cooperation with Karger Publishers, Switzerland.

Nestlé Nutrition Institute (Switzerland) 